\title{
Governance, Economic Policy, and the Environmental Kuznets Curve for Natural Tropical Forests ${ }^{1}$
}

\author{
Authors \\ Corresponding \\ (first) author \\ Madhusudan Bhattarai \\ Post Doctoral Fellow (Economist) \\ International Water Management Institute \\ P.O. Box 2075; Colombo, Sri Lanka \\ Phone: 94-1-787404; Fax: 94-1-786854 \\ Email: m.bhattarai@cgiar.org \\ and \\ Second Author \\ Michael Hammig \\ Department of Agricultural and Applied Economics \\ Clemson University \\ Clemson, South Carolina 29634 USA \\ Phone: 1-864-656-3225 \\ Email: mhammig@clemson.edu
}

\section{Abstract}

This paper reports the results of an empirical analysis of the relationship between income and the rate of deforestation of tropical natural forests. The inverted U-shaped relationship known as the environmental Kuznets curve is confirmed here when it is examined for about 60 countries from the tropical regions of Latin America, Africa, and Asia during the period 1980 to 1995. The study focuses on the role of institutions and governing factors and macroeconomic policies in the tropical deforestation process. Results indicate that the quality of governance and underlying institutions are important determinants of forest resource preservation, and that rural population pressure is not as important as suggested by other studies. Agricultural technology improvement and enhanced educational attainment and social development factors also lead to reductions of deforestation rates.

\footnotetext{
1 A selected paper presented at the Second World Congress of Environmental and Resource Economist, held at Monterrey Bay, California, June 23-28, 2002.
} 


\section{Governance, Economic Policy, and the Environmental Kuznets Curve for Natural Tropical Forests}

\section{Madhusudan Bhattarai and Michael Hammig}

\section{Introduction}

The major objective of this study is to carry out an empirical verification of the Environmental Kuznets Curve (EKC) relationship for deforestation of natural forests in the tropics. The EKC hypothesizes an inverse U-shaped relationship between indicators of environmental deterioration and economic development. During initial stages of development, some form of environmental degradation appears inevitable, but subsequent income increases will produce incentives to improve environmental quality.

The major implications from EKC studies for global environmental policy are to identify potential policy programs in developing countries that move the economy to a sustainable development path. The goal is to find means to tunnel through the potential EKC path by managing the economy within ecological threshold limits. Thus, the EKC is flattened and countries can avoid potential catastrophes while achieving sustainable growth (Munasinghe, 1999; Panayotou, 1995). Prudent policy can minimize the damage done to environmental systems during the development process, thus keeping environmental damage within safe limits.

Forests embody important environmental attributes including carbon sequestration, reduction of greenhouse gas emissions, and the enormous amount of biodiversity resources found in tropical ecosystems (Brown and Pearce, 1994). The tropical deforestation issue is the central focus of many international environmental forums. The UN’s Rio de Janeiro conference in 1992 and Kyoto conference in 1997 
reflect this concern. However, despite international concern for tropical forest loss, the annual conversion of tropical forest to other land use was about 12 million hectares worldwide between 1980 and 1995 (FAO, 1997).

Unlike the case of flow types of pollution, the presence or absence of a Kuznetian functional relationship between income and the indicator of a stock type of environmental quality like forest cover is not clear-cut in the literature (Arrow et al., 1995; Stern, et al., 1996; Ekins, 1997). The present available evidence is mixed, and it varies depending on the sets of countries and time periods selected for the study. Some of the previous studies on economics of deforestation of forest and woodlands (Cropper and Griffiths; 1994; Koop and Tole, 1999; Mather, et al., 1999; Bhattarai and Hammig, 2001) have established an EKC relationship for deforestation. However these studies are based on FAO data on forest and woodlands area, which includes tree crop plantations. This leaves open the question of whether there exists an EKC type of relationship for true forest cover. The lack of a precise measure of the appropriate deforestation process is a serious limitation of previous studies on the topic. This study contributes to this debate by using recently available data from the World Resources Institute (WRI) on natural forest area.

Clearly, forest area can be reduced through harvesting for various purposes. Also, replanting and plantation development can increase forest area. In general the deforestation EKC assumes that low-income countries clear forest area without replacement, or at least that the replacement rate is less than the harvest rate. As incomes grow, investment in forests, by replacing area cut for logging or establishing plantations of forest-producing products, more than compensates for area lost. Likewise, the structure of the economy and energy demand patterns may change when income rises. In 
many countries, fuelwood energy predominates during early stages of development, but coal and petroleum-based fuels become more important during later stages, thereby reducing forest conversion pressure. Thus, there will be a transformation in the structure of the economy as income increases. The model presented here hypothesizes this process to be affected by macroeconomic conditions, institutions, technology, and structural factors.

Developing countries, which for the most part are tropical, account for 59 percent of the total land area of the world and 57 percent of total world forest area (FAO, 1997). Natural closed broad-leaved forests in tropical countries cover about 1,260 million hectares, or nine percent of the Earth's total land area (Barbier, et al., 1991). While annual deforestation was 12 million ha during 1980-95, the loss of natural forest in developing countries was more than 13 million ha annually (FAO, 1997). The difference was compensation by plantation forest replanting.

Whether deforestation activities always produce detrimental effects or whether the present trend of tropical deforestation can be considered as an economic problem at all is debatable. Is there an optimal level of deforestation at any time? The present literature provides mixed results on these topics. Since forestry contributes to national income, the present forest production in the developed countries, which is substantially stabilized, is an outcome of economic development (Walker, 1993). And, the current loss of tropical forest is closely linked to the development process and the institutional and structural constraints affecting that process. Therefore, the forest conversion process is an outcome of economic decision making of a rational agent - an individual frontier farmer, the logging industry, or the state. Economic incentives (full opportunity costs) 
faced by farmers or the state can be explained to a large extent by straightforward economic reasoning.

\section{Literature}

Some of the recent empirical studies on the topic of income growth and environmental quality have shown that some pollutants such as SO2, SMP, nitrous oxides, and river water pollutants follow an inverse U-shaped functional relationship with economic growth (Shafik and Bandhopadhya, 1992; Shafik, 1994; Seldon and Song, 1994; Grossman and Krueger, 1995; Panayotou, 1995; and Yandle and Qin, 1998). Likewise, the inverted U-shaped relationship with income has also been recently shown in the case of deforestation of forest and woodlands ${ }^{2}$ (Cropper and Griffiths; 1994; Koop and Tole, 1999; Mather, et al., 1999; Bhattarai and Hammig, 2001). However, such Kuznetian evidences has not yet been reported for other environmental pollutants including $\mathrm{CO} 2$ and nitrates, the environmental effects of which are difficult to quantify with respect to geographical boundaries. All of these studies have used cross-country time series modeling to investigate the EKC relationship, but with different sets of countries, model specifications, and time periods.

Despite these recent attempts to explain the EKC relationship based on economic intuition and sound theoretical foundations, there is no unanimous view among scholars as to why and how exactly the EKC relationship emerges for certain cases, and not for other environmental indicators. The problem is further complicated by not having an acceptable measure of an indicator representing a broad range of environmental quality. The theoretical exercise depends upon the nature of the indicators in question.

\footnotetext{
${ }^{2}$ Each of these studies used FAO data on forest and woodlands area to measure the deforestation rate.
} 
Arrow, et al. (1995) offered their opinion of the EKC relationship for a stock resource like forests. They asserted that, “An inverted-U relationship has been shown for emissions of pollutants, but is not feasible for stock resources like forest ecosystems. The relation is less likely to hold wherever the feedback effects of forest stocks are significant, such as those involving soil and its cover, forests, and other ecosystems.”

Unlike many other indicators of environmental quality, the relationship between deforestation and income, and associated policy and institutional factors is not straightforward. As forests in most developing countries are managed under public ownership, it is likely that the EKC relationship is linked with various socio-political institutions, structural factors, and historical processes.

Most cross-national studies on deforestation have focused on the impact of population growth (Allen and Barnes, 1985; Cropper and Griffiths, 1994; Koop and Tole, 1999; Mather, et al., 1999). Due to lack of cross-national statistics for other major institutional and macroeconomic policy variables, the impacts of these variables on the deforestation process has not been emphasized. However, some recent attempts by the World Bank’s growth research teams, and other cross-national study centres such as Freedom House publications have provided consistent and comparable institutional statistics across countries. Therefore, there is now the opportunity to follow the reasoning of analysts like Barbier (1997) who suggest that the indirect linkage of income growth to changes in the structure of socio-political institutions leads to feedback effects and increased willingness to pay for environmental quality through these institutional changes. Samuelson (1976) illustrated the importance of institutional impacts - induced by income growth - on the forest harvest decision, and also suggested that institutional effects have influenced forest use decisions since the time of the Romans. 
Norton (1998), using cross-national analysis, found that deforestation is greater in nations with weak property rights. Deacon (1994) obtained similar results. He found that insecure ownership, political insecurity, and political revolutions were all positively related to the deforestation process. Angelsen and Kaimowitz (1999), from a survey of more than 140 economic models analyzing causes of tropical deforestation, reported that more roads, higher agricultural prices, lower wages, and shortage of off-farm employment generally lead to greater deforestation. However, the structural relationships linking these forces are not clearly defined. Several country-specific case studies have identified other factors for deforestation, including prices of round wood, inappropriate road building and infrastructure development, weak institutions to enforce rules and regulations, and tenure insecurity (Barbier, 1997; Burgess, 1992; Southgate and Runge, 1990; Southgate, et al. 1991).

Some recent micro-level institutional analyses of forest resource management in developing countries have also identified the importance of governance to forest resource use decisions. For example, Gibson, et al. (2000), based on multi-country village level studies, reported that the combination of national, regional, and local institutions play a critically important role in the consumption of forest resources.

\section{Conceptual Model of the Deforestation EKC}

Most of the previous econometric studies on the relationship between deforestation and economic development controlled for population factors alone. Unlike those studies, the EKC relationship is estimated in this study first by isolating the net impacts of policy variables on deforestation and then estimating EKC models controlling for selected socio-political institutions, macroeconomic policy variables, technological change in the agricultural sector, and population factors. 
This study hypothesizes that economic development is first accompanied by deterioration of environmental quality, but once societal income reaches a sufficiently high level environmental quality will improve. Deforestation is considered here as the indicator of environmental degradation. It is assumed that increases in income are accompanied by improvements in socio-political institutions and better allocation of environmental resources, which are generally public goods. Hence, it is further hypothesized that underlying institutional and policy conditions affect the relationship between deforestation and income. This study adopts the same empirical procedures employed by others (e.g. Grossman and Krueger, 1991; Panayotou, 1995) but with the addition of institutional factors and broad level macroeconomic variables hypothesized to affect the income-deforestation relationship.

\section{Empirical Models}

The relationship between economic development and deforestation is analysed using cross-section time series regression, i.e., panel data analysis. Some studies of the EKC for deforestation have used single-period cross-sectional data (Mather, 1999; Antle and Heidebrink, 1995) and other studies (Shafik, 1994; Cropper and Griffiths, 1994; Koop and Tole, 1999; Bhattarai and Hammig, 2001) have applied panel data techniques. The results in these studies vary depending on the type of econometric technique used and the variables selected for the study.

The impacts of institutional and policy variables can be revealed by cross-country analysis which provides for wide variation of institutions. Panel data analysis allows the study of dynamic as well as cross-sectional aspects of the problem, and is therefore considered better for analyzing complex relationships, generalizing empirical findings, and conducting theoretical modeling exercises. Panel data control for the country and 
time invariant variables. Time-series or cross-section studies alone cannot control such individual heterogeneity in data sets (Baltagi, 1995). Though the process for deforestation varies across countries and regions, the fixed effect panel regression technique allows estimation of common coefficients for selected variables, while allowing structural constraints to vary across the countries. Therefore, the fixed effect technique is preferred for cross-country analysis where the sample is not drawn randomly from the population (Green, 1997; Hsiao, 1986).

The empirical model adopted in this study is,

$$
D F_{i t}=\alpha_{i}+\beta_{1} Y_{i t}+\beta_{2} Y_{i t}^{2}+\beta_{3} T_{i t}+\beta_{4} A_{i t}+\beta_{5} I_{i t}+\beta_{6} X_{i t}+\beta_{7} P_{i t}+u_{i t}
$$

where,

$$
\begin{aligned}
& \mathrm{DF}_{\mathrm{it}}=\text { deforestation rate for county } \mathrm{i} \text { in period } \mathrm{t}, \\
& \mathrm{Y}_{\mathrm{it}}=\text { GDP per capita, } \\
& \mathrm{T}_{\mathrm{it}}=\text { time trend, } \\
& \mathrm{A}_{\mathrm{it}}=\text { agricultural sector variables, } \\
& \mathrm{I}_{\mathrm{it}}=\text { institutional variables, } \\
& \mathrm{X}_{\mathrm{it}}=\text { macroeconomic policy variables, } \\
& \mathrm{P}_{\mathrm{it}}=\text { population variables, and } \\
& \mathrm{u}_{\mathrm{it}}=\text { random error. }
\end{aligned}
$$

Two approaches are used to estimate this model. WRI data on natural forest area are used to specify the dependent variable. To conserve degrees of freedom and to investigate the singular impact of key factors, following the procedure used by Shafik

(1994), separate models are estimated using the basic EKC relationship with each policy variable. That is, each of the policy, population, and institutional variables is entered in a 
separate estimation of the basic model of income, time trend, and a scaling variable of per capita forest land in each country.

The second approach provides further insight into the institutional impact on deforestation. The fully specified model was estimated with a complete set of policy and population variables, applying alternative specifications of the institutional factors hypothesized to affect deforestation. Different institutional specifications are separately estimated to avoid multicollinearity and to test for possible differences between the two measures of institutional quality.

The deforestation process is influenced by a complex set of factors. Controlling for institutional and policy factors in the empirical model ensures reliable estimates of the income effects on deforestation. However, the empirical models presented in this study are proxy models. Factors underlying the deforestation decision are identified in the models. These factors both directly and indirectly influence the proximate variables (output prices and input costs) faced by the agents (farmers as well as governmental authorities) involved in the forest harvesting decision. Therefore these models represent the economic and institutional context within which the markets for forest products operate.

\section{Data}

The relationship between the deforestation rate and income is examined for 63 countries from the tropical regions of Latin America, Africa, and Asia during the period 1980 to 1995 . Observations of forest cover for each country are available for 1980, 1990, and 1995. The data set is composed of information from 20 countries in Latin America, 31 in Africa, and 12 in Asia that fit the geographical restriction and for which consistent and comparable data for natural forest cover are available for each of the three time 
periods. Institutional data on governance are not available for several countries in Africa; therefore, the regression models including the governance variable are estimated for only 55 countries.

Detailed descriptions of the explanatory variables are given in Table 1 . There is no unanimously accepted data source for measurement of tropical forest as such. Past studies of the economics of deforestation have used FAO statistics on forest and woodlands to derive the deforestation rate (Cropper and Griffiths, 1994; Koop and Tole, 1999; Bhattarai and Hammig, 2001). This study provides a comparison with previous efforts by specifying a model with a different definition of forest area provided by WRI.

\section{Natural Forest}

Cross-country statistics on natural forest cover have recently become available for the years 1980, 1990, and 1995 (WRI, 1998-99). This is the natural forest cover observed by the Landsat satellite, which was later verified using GIS and field observation data and compiled by the Global Environmental Monitoring Systems (GEMS) and FAO. 
Table 1. Variable definitions and their expected relationship with the deforestation rate

\begin{tabular}{|c|c|c|c|}
\hline $\begin{array}{l}\text { Explanatory } \\
\text { Variable }\end{array}$ & Unit & Description & xpected Sign \\
\hline GDP & US\$1000 & $\begin{array}{l}\text { PPP adjusted per capita GDP } 1985 \text { US dollars } \\
\text { (1 year lag) }\end{array}$ & Positive \\
\hline GDP Squared & & & Negative \\
\hline TIME & & $\begin{array}{l}\text { An indicator of other exogenous } \\
\text { time dependent variables }\end{array}$ & No prediction \\
\hline Population Growth & $\%$ & $\begin{array}{l}\text { Annual percentage population growth rate } \\
\text { (1 year lag) }\end{array}$ & Positive \\
\hline Rural Pop Density & & Rural population per 1000 square km & Positive \\
\hline Political Institutions & index & $\begin{array}{l}\text { Sum of political rights and civil liberties } \\
\text { indices }(2-14)\end{array}$ & Negative \\
\hline Governance & & $\begin{array}{l}\text { Sum of indices of rule of law, bureaucratic qua } \\
\text { and corruption in government }(3-18)\end{array}$ & Negative \\
\hline Change in Cereal Yield & $\%$ & Annual percentage change in cereal yield & No prediction \\
\hline Ag Value Added & $\%$ & Agricultural value added (per ha) & No prediction \\
\hline Black Mkt FOREX & $\%$ & Black market premium on foreign exchange & No prediction \\
\hline Debt/GDP & $\%$ & Measure of debt burden in the economy & Positive \\
\hline Sec School Enrolment & $\%$ & $\begin{array}{l}\text { Percentage of eligible adult population enrollec } \\
\text { secondary schools }\end{array}$ & Negative \\
\hline Economic Growth Rate & $\%$ & $\begin{array}{l}\text { Annual \% change in GDP per capita adj. for } \\
\text { inflation and population growth rates }\end{array}$ & Negative \\
\hline Annual Inflation Rate & $\%$ & Annual change in GDP deflator & o prediction \\
\hline Real Exchange Rate & index & $\begin{array}{l}\text { Real exchange rate } \\
\text { change in local CPI with the US CPI }(1995=10\end{array}$ & $\begin{array}{l}\text { o prediction } \\
0 \text { ) }\end{array}$ \\
\hline Terms of Trade & index & Terms of trade (goods and service, $1995=100$ ) & No prediction \\
\hline $\begin{array}{l}\text { Source: } 1 \text {. Deforestation } \\
\text { 2. The macroeconomic } \\
\text { Growth Rate are obtaine } \\
\text { 3. Population Growth, R } \\
\text { The World Bank's Worl } \\
\text { 4. Cereal yield statistics } \\
\text { 5. Indices included in Pc } \\
\text { http://www.freedomhou }\end{array}$ & $\begin{array}{l}\text { ate is derive } \\
\text { riables GDF } \\
\text { from the W } \\
\text { ral Pop Den } \\
\text { Developme } \\
\text { e obtained } \\
\text { tical Institu } \\
\text {.org/ }\end{array}$ & $\begin{array}{l}\text { change in natural forest area (WRI 1998-99). } \\
\text { k Mkt FOREX, Debt/GDP, Inflation Rate, and } \\
\text { wth Datasets, at http://www.worldbank.org/gro } \\
\text { ec School Enrollment and Terms of Trade are o } \\
\text { ort CD Rom data sets (1998). } \\
\text { ee World Resource Institute data sets (WRI, } 199 \\
\text { re obtained from Freedom House at }\end{array}$ & $\begin{array}{l}\text { Economic } \\
\text { wth/index.htm. } \\
\text { btained from } \\
\text { 8-99). }\end{array}$ \\
\hline
\end{tabular}


The data on natural forests allow estimating two periods of change in forest cover (1980 to 1990 and 1990 to 1995). Annual averages of the other explanatory variables were also calculated to construct a consistent data set. Due to the limited number of observations, only the quadratic form of deforestation EKC models was estimated. Higher order models used in other studies were not practicable here. Heretofore, no previous study on the EKC, or other aspect of deforestation, is based on this definition of natural forest area.

Income

Purchasing power parity adjusted GDP per capita, in 1990 US dollars, is used as the national income measure. These data are obtained from the Summers and Heston (1991) data sets. The World Bank’s research groups have expanded and updated these data to 1997. As the theory of the EKC suggests, it is expected that the coefficient of the GDP per capita term is positive, and the coefficient of the quadratic GDP per capita term is negative.

\section{$\underline{\text { Agricultural Sector Growth }}$}

The relationship between growth of the agricultural sector and deforestation is captured by variables tracking improvements in productivity and growth of agricultural value-added. Agricultural productivity changes affecting cereals production is hypothesized to reduce the need to clear forest areas for agriculture. Increases in agricultural value-added are hypothesized to provide income generating opportunities for rural populations as a substitute for extraction of forest resources.

\section{$\underline{\text { Institutions }}$}

Two different institutional indices are included in the EKC model. One, Political Institutions, represents democratic access (political rights and civil liberty indices), as compiled and reported by Freedom House. The other, Governance, represents the quality 
of government institutions, and is more concerned with the functioning of these institutions. This includes practice of impartial rule of law, quality of government bureaucracy, and corruption in the government. The term governance refers to the manner in which power is exercised in the management of a country's economic and social resources for development and other activities (Isham, et al., 1997). The same applies to the quality of governmental forest authorities and their functioning for management of forest resources.

The political institutions variable is created by summing political rights and civil liberties indices obtained from Freedom House publications described by Scully (1992) and Gastil (1987). Each index has a value from one to seven and is based on a list of specific criteria. They are published in the Freedom House yearly publications. ${ }^{3}$ Several recent studies on the relationship between institutions and economic growth and development have used these indices; for example, Barro (1996) and Isham, et al. (1997).

The original Freedom House political rights index value is one for countries with the most political freedom country (U.S.) and seven for the least political freedom (Afghanistan). However, for consistent interpretation of the regression results and to have a comparable outcome with other variables, these indices are reversed in order so that the higher number indicates more political freedom and a higher level of civil liberty. Summing these two indices creates the Political Institutions variable, which ranges from two to 14 . The cardinal measure of the index rather than an ordinal (or dummy variable method) allows us to quantify the impact of marginal improvement of institutional factors on the deforestation process.

\footnotetext{
${ }^{3}$ Details of the indices are found in Scully (1992) and Freedom House publications at the website, http://www.freedomhouse.org.
} 
The governance variable is created by summing three different indices from IRIS data sets published by the Political Risk Services Group, a private consulting firm engaged in international risk assessment for foreign investment. The Governance variable is the sum of indices of rule of law, quality of bureaucracy, and corruption level. All three have values one through six, so the composite variable takes on values three through 18. Details of these IRIS indices are given in Knack and Keefer (1995). Panayotou (1997) used IRIS data in his EKC study. It is expected that improvement in the institutional variables will have negative impacts on the deforestation rate, thus lowering the EKC for deforestation.

\section{$\underline{\text { Macroeconomic policy and population }}$}

The macroeconomic policy variables selected for the empirical model are foreign debt as a percentage of GDP and black market premium on foreign exchange. Structural variables including annual growth of GDP per capita and secondary school enrolment are also included. The population factors used in the model are population growth rate and rural population density.

\section{Results and Discussion}

\section{Individual Models}

The results from separate models for each of the policy variables in the basic deforestation EKC model are reported in Table 2. The dependent variable is the annual average deforestation rate of natural forest land for the sample countries for the periods 1980-90 and 1991-95. This approach conserves degrees of freedom and avoids multicollinearity. It also isolates the net impact of each of the policy variables on deforestation in the framework of the EKC. The EKC relationship is observed in all cases in Table 2. The coefficient of GDP is positive and the quadratic GDP term is 
negative for all the equations estimated. The adjusted R-squares are sufficiently high to suggest the overall explanatory power of the model is satisfactory.

The time trend variable is negative for most of the models shown in Table 2, which means the trend of the weighted average tropical deforestation rate is declining over the recent past. The forest per capita variable, which controls for the scale effects across countries, is not statistically significant in most cases. The adjusted R-square for the basic EKC model of .69 suggests that income explains a substantial portion of the variation in deforestation of natural forest in the tropics. This explanatory power is considerably higher than that reported by Shafik (1994) for his model of forest and woodlands deforestation. Considering the importance of scale effects across countries, the fixed-effect GLS panel regression provides better parameter estimates than the simple OLS technique adopted by Shafik (1994) and other earlier studies on the topic.

The population growth variable is positive and statistically significant, which is consistent with the commonly accepted perception (equation 2). However, the rural population density variable is negative and statistically significant (equation 3). This implies that deforestation is not taking place where the rural population pressure is highest; indeed the opposite occurs. Templeton and Scherr (1999) note that once rural population pressures increase to a sufficient level and forest becomes sufficiently scarce, society tends to improve forest protection. 
TABLE 2. Factors Affecting Annual Average Deforestation Rate Of Tropical Natural Forest, 1980-95 Independent Variables/

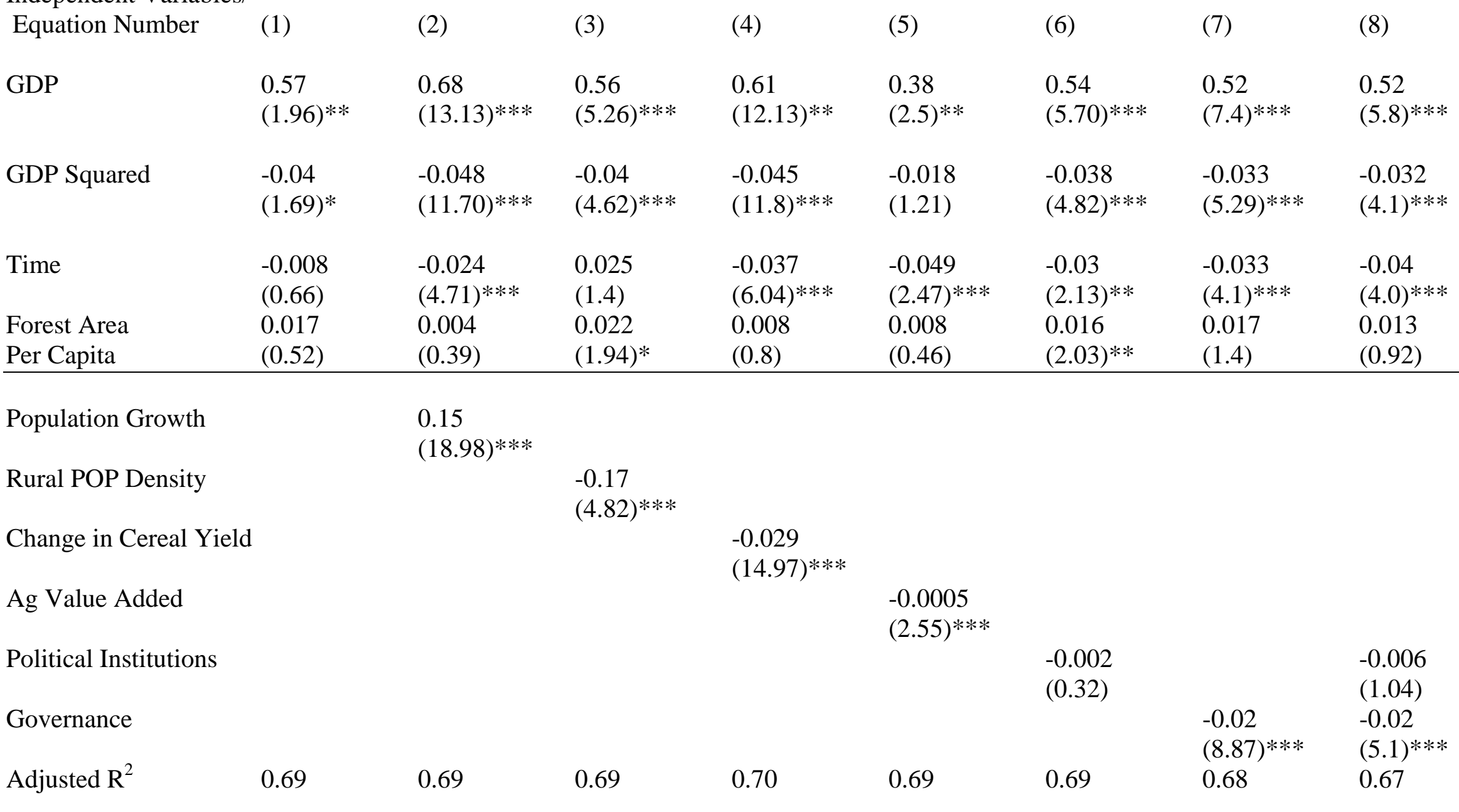

Note: F statistics are significant at $1 \%$ level for all regression models. Values in parentheses are absolute t- statistics, $*=$ significant at $10 \%, * *=$ significant at $5 \%, * * *=$ significant at $1 \%$. 
Table 2. continued

\begin{tabular}{|c|c|c|c|c|c|c|c|c|}
\hline \multicolumn{9}{|l|}{ Independent Variables/ } \\
\hline & $(6.75) * * *$ & $(7.39) * * *$ & $(9.03) * * *$ & $(9.77)^{* * *}$ & $(9.01) * * *$ & $(7.14)^{* * *}$ & $(10.1)^{* * *}$ & $(1.84)^{*}$ \\
\hline Time & -0.041 & -0.044 & -0.14 & -0.11 & -0.03 & -0.00004 & -0.049 & -0.06 \\
\hline & $(2.49) * * *$ & $(4.02)^{* * *}$ & $(8.81)^{* * *}$ & $(12.1)^{* * *}$ & $(2.84) * * *$ & $(0.006)$ & $(4.9)^{* * *}$ & $(3.4) * * *$ \\
\hline Debt \% of GDP & $\begin{array}{l}0.0004 \\
(0.33)\end{array}$ & & & & & & & \\
\hline Economic Growth Rate & & $\begin{array}{l}-0.017 \\
(8.65)^{* * *}\end{array}$ & & & & & & \\
\hline Real Exchange Rate & & & $\begin{array}{l}-0.0017 \\
(7.44)^{* * *}\end{array}$ & & & & & \\
\hline Terms of Trade & & & & & & $\begin{array}{l}0.0027 \\
(11.12)^{* * *}\end{array}$ & & \\
\hline Sec School Enrolment & & & & & & & $\begin{array}{l}-0.032 \\
(11.33)^{* * *}\end{array}$ & \\
\hline Governance * GDP & & & & & & & & $\begin{array}{l}0.000006 \\
(2.9)^{* * *}\end{array}$ \\
\hline Adjusted $\mathrm{R}^{2}$ & 0.69 & 0.70 & 0.70 & 0.69 & 0.71 & 0.70 & 0.69 & 0.67 \\
\hline
\end{tabular}


This is contradictory to the population thesis of deforestation mentioned in previous deforestation studies (Myers, 1991 and 1994; Allen and Barnes, 1985; Cropper and Griffiths, 1994; Palo, 1994). These results indicate that the driving force for excessive tropical deforestation in the recent past is urban population pressure, or urban bias in developmental policy to provide urban fuelwood, wood products, and timber or saw wood for growing urban populations.

Consistent with the EKC hypothesis, the coefficient of the agricultural technology change variable in equation 4 is negative and statistically significant, suggesting that improvements in agricultural productivity reduce the pressure to convert forestland to agricultural uses. By contrast, some of the previous empirical evidence of this relationship is not so straightforward (Angelsen and Kaimowitz, 1999). Likewise, the model suggests that agricultural value-added also lowers the pressure on natural forest conversion in the tropics (equation 5).

These results indicate that modernization of the agricultural sector provides incentives to preserve natural forests in the long run, thus reinforcing the EKC hypothesis for deforestation. This is an important difference between models explaining natural forest loss and deforestation of forest and woodlands as discussed in previous studies (Bhattarai and Hammig, 2001). The results from the natural forest models provide evidence that improvement of agricultural technology and modernization in farming reduces pressure on the deforestation of natural forests in tropical regions ceteris paribus.

The political institutions variable, given in equation 6, is negative but not statistically significant. However, the governance variable (equation 7) is negative and statistically significant. This implies that improving the quality of governance, i.e., 
improvements in the rule of law, the quality of bureaucracy, and reducing corruption in governmental agencies will lower the deforestation level of natural forest in the tropics, ceteris paribus.

A separate model including both political institutions and governance was estimated to further investigate these relationships. Results are shown in equation 8. Again the governance variable is statistically significant and negative, with no other major changes in the signs or significance of other variables. This result emphasizes the importance of governance on natural resource use. The governance factor can be referred as the social function of government, or the social structure underlying policy making institutions (Isham, 1997). Considering the fact that more than 85 percent of forest and woodlands in developing countries and almost all tropical natural forests are in public lands (Repetto and Gillis, 1988), the importance of governance is not surprising.

The impacts of selected macroeconomic policy variables on deforestation of natural forest are provided in equations 9 through 14. External debt is frequently cited as a critical determinant of deforestation in the tropics (Kahn and McDonald, 1995). In this model, its coefficient is positive but statistically not significant. The net impact of external debt varies by countries and regions; therefore, a clear impact is lost in the aggregation process. Bhattarai and Hammig (2001) found positive impacts of debt in regional EKC models of forest and woodlands, but the level of significance varied. This is plausible considering the fact that debt management was a major concern in Latin America in the late 70s and early 80s, but not so severe in Asia and Africa.

The annual economic growth rate is negative and statistically significant. This implies that the deforestation level of natural forest falls as economic growth increases 
and that economic growth is not inconsistent with protection of natural resources, ceteris paribus.

The real exchange rate has a negative and statistically significant impact on deforestation, as seen in equation 11 . This means that strengthening of the value of local currency with respect to foreign currencies will reduce pressure on the natural forest ecosystem. Exchange rate management is a key macro policy function of government; however, the role of the exchange rate in the deforestation process is not clear-cut Repetto and Gillis, 1988). Recent empirical studies on the topic have reported conflicting results in the case of deforestation EKC models for forest and woodlands (Shafik, 1994; Bhattarai and Hammig, 2001). Since no previous studies have used the natural forest data to measure deforestation, this result can be considered an initial comment in the debate that will follow over the role of the exchange rate. The empirical results here suggest that strengthening of the local currency discourages the export of tropical timber and sawn woods, thus decreasing the tropical deforestation level. This also emphasizes the importance of the relationship between macroeconomic policy management and natural resource use management.

The black market premium on foreign exchange, which also measures the overall macro policy environment, including exchange rate as well as trade policy, is negative and statistically highly significant. The black market rate on foreign exchange, in addition to the exchange rate's impact, also measures trade openness. The result in equation 12 indicates that the higher the black market premium on foreign exchange, the lower the loss of natural forest. This appears counterintuitive but reflects real world evidence. High levels of logging of tropical rain forest is observed in countries such as 
Indonesia, Malaysia, Thailand, Brazil, and the Philippines, which have adopted relatively open trade policies in the recent past. Large export markets for tropical logs, and government subsidies and other concessionary policies in exporting countries, are some of the leading causes of the high level of tropical deforestation in these countries. High black market premiums on foreign exchange would suggest a relatively closed economy, which is not typical of the major tropical forest product exporters.

The annual inflation rate (equation 13) has a negative coefficient, but is statistically insignificant. The impact of inflation on deforestation would be observed in the investment in labour and capital needed to harvest natural forests. Thus, a negative impact would be expected because high inflation may deter forest harvesting by logging and timber companies.

The terms of trade variable in equation 14 is positive and significant, suggesting that the governmental motive to generate foreign currency by allowing for export of tropical logs is an important driver of deforestation in the tropics. This result reinforces the findings for the real exchange rate and the black market premium on foreign exchange.

Secondary school enrolment is statistically significant and negative (equation 15). Thus improvement in education, which leads to increased off-farm work opportunities and rising wage rates of rural populations, would also lower the pressure on natural forest, ceteris paribus. Case studies have also reported the importance of off-farm employment to tropical deforestation (Ehrhardt-Martinez, 1998; Angelsen and Kaimowitz, 1999). Although rural wage rates and rural employment data for crosscountry comparisons are not available, limiting the breadth of empirical studies on this 
topic, the results here provide empirical evidence that education mitigates the tropical deforestation process.

An interaction term relating GDP and governance is introduced in equation 16. The positive and significant coefficient of this interaction term indicates that the income effect on deforestation depends on the level of institutional development. Improved governance fosters better management of forests and the natural environment even at lower income levels. This result also suggests that the institutional impacts will be relatively larger at lower income levels. But, at higher income levels, the institutional impacts may be counterbalanced by the income effect.

\section{Complete EKC Model}

The complete set of independent variables given in the theoretical model was estimated and results are reported in Table 3. By estimating a fully specified model, the results in Table 3 are more efficient than the results in Table 2. Because of the hypothesized importance of institutions to the management of natural resources, three models are presented in Table 3 representing alternative specifications of the institutional impact.

The results confirm the Kuznets relationship. Significant positive GDP terms and negative quadratic GDP terms are observed in all models in Table 3. That is, the inverted U-shaped relationship between deforestation and income is observed in the case of natural forest, thus confirming the results found in forest and woodlands models in previous studies (Cropper and Griffiths, 1994; Mather, et al., 1999; Bhattarai and Hammig, 2001). 
Table 3

Kuznets Relationship For The Annual Deforestation Rate Of Natural Tropical Forest.

\begin{tabular}{|c|c|c|c|}
\hline Independent Variable & Model 1 & Model 2 & Model 3 \\
\hline GDP & $\begin{array}{l}1.08 \\
(6.08)^{* * *}\end{array}$ & $\begin{array}{l}1.02 \\
(6.38)^{* * *}\end{array}$ & $\begin{array}{l}0.93 \\
(4.17)^{* * *}\end{array}$ \\
\hline GDP Squared & $\begin{array}{l}-0.076 \\
(5.48)^{* * *}\end{array}$ & $\begin{array}{l}-0.071 \\
(5.08)^{* * *}\end{array}$ & $\begin{array}{l}-0.078 \\
(3.82)^{* * *}\end{array}$ \\
\hline Governance & $\begin{array}{l}-0.028 \\
(3.02)^{* * *}\end{array}$ & & $\begin{array}{l}-0.056 \\
(3.04)^{* * *}\end{array}$ \\
\hline Political institutions & ------ & $\begin{array}{l}-0.0066 \\
(1.21)\end{array}$ & ----- \\
\hline GDP * Governance & ------ & & $\begin{array}{l}0.000011 \\
(1.66)^{*}\end{array}$ \\
\hline Economic Growth Rate & $\begin{array}{l}0.0034 \\
(0.56)\end{array}$ & $\begin{array}{l}-0.021 \\
(6.71)^{* * *}\end{array}$ & $\begin{array}{l}0.0022 \\
(0.31)\end{array}$ \\
\hline Debt/GDP & $\begin{array}{l}0.0011 \\
(2.21)^{* *}\end{array}$ & $\begin{array}{l}0.00065 \\
(1.61)\end{array}$ & $\begin{array}{l}0.00054 \\
(0.95)\end{array}$ \\
\hline Change in Cereal Yield & $\begin{array}{l}-0.046 \\
(9.81)^{* * *}\end{array}$ & $\begin{array}{l}-0.028 \\
(7.42)^{* * *}\end{array}$ & $\begin{array}{l}-0.038 \\
(6.11)^{* * *}\end{array}$ \\
\hline Sec School Enrolment & $\begin{array}{l}-0.024 \\
(6.56)^{* * *}\end{array}$ & $\begin{array}{l}-0.023 \\
(6.85)^{* * *}\end{array}$ & $\begin{array}{l}-0.019 \\
(3.98)^{* * *}\end{array}$ \\
\hline Population Growth & $\begin{array}{l}0.52 \\
(10.85)^{* * *}\end{array}$ & $\begin{array}{l}0.12 \\
(2.04)^{* *}\end{array}$ & $\begin{array}{l}0.47 \\
(8.58)^{* * *}\end{array}$ \\
\hline Rural POP Density & $\begin{array}{l}-0.00009 \\
(2.79)^{* * *}\end{array}$ & $\begin{array}{l}-0.00021 \\
(10.22)^{* * *}\end{array}$ & $\begin{array}{l}-0.00007 \\
(2.47)^{* *}\end{array}$ \\
\hline Forest Area Per Capita & $\begin{array}{l}-0.13 \\
(4.19)^{* * *}\end{array}$ & $\begin{array}{l}-0.004 \\
(0.14)\end{array}$ & $\begin{array}{l}-0.14 \\
(4.83)^{* * *}\end{array}$ \\
\hline Adjusted R² (Un-weighted) & 0.67 & 0.67 & 0.66 \\
\hline Number of countries & 55 & 63 & 55 \\
\hline Number of observations & 108 & 124 & 108 \\
\hline EKC turning point & $\$ 7,080$ & $\$ 7,140$ & $\$ 5,940$ \\
\hline
\end{tabular}

Note: 1). Values in parentheses are absolute t-statistics; * = significant at $10 \%, * *=$ significant at $5 \%, * * *$ $=$ significant at $1 \%$. F statistics of above models are significant at $1 \%$.

2). All models were estimated as fixed effects panel regressions using GLS. 
To better understand the impacts of the institutional variables, alternative specifications of the institutional impacts are explored. Model 1 is specified with the governance variable. Model 2 is specified with the political institutions variable. And model 3 is specified with governance and an interaction term associating governance and income.

The coefficient of governance is negative and statistically significant in model 1. This confirms the result obtained in the governance model in Table 2 and is consistent with the fact that most natural forest worldwide is under the direct control of government authority.

The results of model 2 show the political freedom variable is negative but not statistically significant. There are no major sign changes between models 1 and 2 except for the economic growth variable. It is not significant when controlling for the governance variable, but is negative and statistically significant when controlling for political institutions. This could be due the fact that economic growth and the effect of governance go hand in hand, and the governance variable dominated the impact of economic growth in model 1.

The net impact of government institutions on management of natural resources is isolated from the income effect by introducing the interaction of the governance and GDP variables in model 3. The statistically significant and negative coefficient of governance, even controlling for the interaction effect between income and governance, provides further evidence of the importance of governmental institutions and implementing agencies in the tropical deforestation process in the recent past. These results are plausible considering real world evidence. Some of the previous empirical studies on the 
topic of institutions and development have reported that increasing citizens' voice and public accountability - hence improved governance - can lead to greater efficacy of government action and better performance of development projects (Isham, et al., 1997). This study supports this proposition in the case of tropical forest management.

The coefficient of external debt is positive in all three models, as would be expected, but it is statistically significant only in model 1. Debt relief policy for the least developed tropical countries is a frequently discussed public policy issue. Debt-fornature swap programs supported by international NGOs are commonly suggested as a solution for the conservation of tropical forest ecosystems. Supporters of debt-for-nature swaps argue that these programs provide a financing mechanism and an incentive for long-run protection of tropical rainforests. The statistical results found here support this approach.

The percentage change in cereal yield - a proxy for agricultural technology change - is negative and statistically significant in all models in Table 3. These results suggest that an improvement in the cereal yield, i.e., an overall improvement in technology in the agricultural sector, will reduce the degradation of natural resources in the tropics. The existing literature on the role of agricultural yield performance on the tropical deforestation is mixed. Angelsen and Kaimowitz (1999) reviewed more than 140 empirical studies on deforestation and found no conclusive evidence to relate agricultural yield improvement and deforestation. Results vary by regions and local conditions. The empirical results in this study provide evidence of beneficial role of cereal yield improvement in managing forests. 
The secondary school enrolment variable is negative and statistically significant in all models in Table 3. This implies that an improvement in education and human capital ultimately reduces pressure on natural forests in the tropics. Based on very limited studies dealing with education policy and its impacts on environmental management issues, there is no a priori expectation for the sign of the education variable in a deforestation model. However, the negative sign is consistent with the some of the recent studies on social aspects of deforestation issues (Ehrhardt-Martinez, 1998) and micro level studies in Latin America (Godoy, et al., 1998).

Improved education could mean increased possibility of off-farm work and/or migration from rural to urban areas. In an institutional sense, education may also infer better enforcement of laws and regulations, better public participation in the political process, and better environmental awareness. Education enhances human capital, which facilitates adoption of improved technology. In addition to these factors, the education variable may also be capturing the impact of the skewness of income inequality. ${ }^{4}$ Extremely skewed income inequality is considered one of the leading causes of excessive deforestation in Latin America (Binswanger, 1991).

Population distribution and the aggregate population growth rate are hypothesized to affect deforestation. The population growth rate coefficient is positive and statistically significant in all models in Table 3. This implies that population pressures have increased the deforestation of natural forests, which is consistent with the commonly accepted notion that population growth speeds the environmental degradation process. However, to further investigate the impacts of population, a rural population density 
variable was also introduced in the model. Interestingly rural population density, which measures the local population pressure on natural forest cover, is negative and statistically significant for all three models in Table 3. This suggests that deforestation of natural forest does not take place in regions where rural population pressure is high. The opposite signs of the two population variables suggest that the deforestation of natural forest is driven by urban population growth rather than rural population pressure. This contradicts Myers (1991 and 1994) and Palo (1994) who attribute tropical deforestation to growth of populations of peasants and frontier inhabitants.

These results underscore the importance of institutional and policy factors related to population growth. In particular, agricultural terms of trade are frequently biased against rural residents in developing countries due to subsidies for urban populations. Growing urban areas increase the demand for forest products providing a stimulus for deforestation activities. Unlike the deforestation models using FAO forest and woodlands data in which positive coefficients for rural population density were found, rural population density has an opposite impact in the case of natural forests. The findings in this study contradict the neo-Malthusian version of the deforestation process, which cite rural population growth and shifting cultivation practices as the primary factors responsible for excessive forest destruction worldwide (Myers, 1994; Myers 1991; Allen and Barnes; 1985; Cropper and Griffith, 1994; Palo, 1994). By contrast, some previous empirical studies on deforestation of forest and woodlands report a negative sign for the population growth factor (Shafik, 1994; Southgate, 1994; Koop and

\footnotetext{
${ }^{4}$ An annual income inequality variable is not available for all the countries selected here; however, Sokoloff and Engerman (2000) suggest that in the long run the average education and literacy rates will be higher in a society with relatively low income inequality.
} 
Tole, 1999). Thus the impact of population factors on deforestation remains controversial.

The rural population factor does not appear to be a strong cause of natural forest loss when we control for other economic and institutional variables in the deforestation model. Bhattarai (2000) estimated regional models of deforestation and reported that the rural population density impact was strongly negative in Asia, which could be due to the high concentration of population in urban areas in Asia compared to Latin America and Africa. This evidence indicates that the large-scale deforestation of natural forests in the tropics is not taking place where population density is high. For example, deforestation of natural forest in recent years was highest in Papua New Guinea, Brazil, Malaysia, Thailand, and the Philippines, where the rural population density is relatively low compared to other sample countries. Hence, it is not the rural population pressure, but some other factors that drive the deforestation process in the tropics.

Only two point estimates of the deforestation rate of natural forests are available for each country; therefore, forest area per capita is included to minimize the scale effect bias across the wide variation of forest areas found in the sample countries. The coefficient of the per capita forest area variable is negative in all cases and statistically significant in models 1 and 3 . This suggests that the overall deforestation rate of natural forests is lower in countries with relatively high per capita natural forest coverage.

The negative quadratic GDP term was observed in all models in Table 3, confirming the EKC relationship for deforestation of natural tropical forests. By solving the quadratic equation of the models, the turning points of the deforestation/income relationship can be found. The turning point income of the EKC is US\$7,080 for model 1 
and US\$7,140 for model 2. The turning point income of $\$ 5,940$ with the interaction term in model 3 is lower than the other cases. Thus the EKC for natural forests implies that we can expect developing countries with tropical forests and incomes below $\$ 6,000$ 7,000 to continue to lose natural forest lands. ${ }^{5}$ When incomes grow above those levels, conservation efforts will become effective and the deforestation trend will reverse. Few countries in the sample have incomes above these levels. For most sample countries the EKC turning point is substantially higher than current incomes. This suggests that income growth alone may not be able to check the present deforestation trend in the tropics.

Prudent macroeconomic policies and attention to institutional structure are also critically important to the tropical deforestation process.

\section{Conclusions}

This study contributes to the literature of the EKC in general, and the EKC for deforestation in particular. Empirical results presented here focus on the depletion of natural tropical forests. The natural forest data, published by WRI, provide an improved definition of the deforestation process over previous studies using FAO data. Previous empirical studies of the global EKC for deforestation provide mixed evidence of the validity of the deforestation EKC relationship. This study confirms the EKC for deforestation in tropical developing countries and asserts that quality of institutions plays a vital role in the protection of forest resources.

Results of this study should be interpreted cautiously since the estimated models do not represent any specific country or locality where deforestation activities are taking place. However, the results from cross-national analysis are useful for validating or refuting some of the controversial theoretical issues discussed in the literature. This

\footnotetext{
${ }^{5}$ Countries selected for the study and their 1990 real incomes are given in Appendix Table 1.
} 
cross-country empirical analysis provides information for global policy recommendations as well as input for further theoretical exercises on the subject. The results in this study provide confirmation of the global environmental protection concept embodied in the EKC.

The EKC model for natural forest confirms that quality of governance is a critical determinant of tropical deforestation. Among the macroeconomic policy factors selected for the EKC models, increases in economic growth, the real exchange rate, and the black market premium on foreign exchange reduce deforestation of tropical natural forests.

Despite the emphasis given to local population pressure, shifting cultivation, and slash and burn agriculture in the literature on the economics of deforestation it appears that local population pressure is not a primary driving force for the depletion of natural forests. However, overall population growth does have a positive impact on deforestation.

The change in cereal yield and secondary school enrolment -proxies for technology change in the agrarian sector and human capital development, respectively were both found to deter the deforestation process. These results are consistent with the basic concept of the EKC hypothesis, which suggests that economic development is consistent with improved environmental quality. Improvements in education provide opportunities for off-farm employment, facilitate technology adoption, and improve public participation in the democratic process. Thus, the empirical evidence from this study demonstrates that both technological and social development will have favourable impacts on the conservation of natural forests. 


\section{References}

Allen, J.C., and D.F. Barnes (1985), 'The causes of tropical deforestation in developing countries', Annals of the Association of American Geographers 75: 163-84.

Angelsen, A. and D. Kaimowitz (1999), 'Rethinking the causes of deforestation: Lessons from economic models’, The World Bank Research Observer 14: 73-98.

Antle, J.M., and G. Heidebrink (1995), 'Environment and development: Theory and international evidence’, Economic Development and Cultural Change 43: 603625.

Arrow, K., B. Bolin, R. Costanza, P. Dasgupta, C. Folke, C. S. Holling, B. Jansson, S. Levin, K. Maler, C. Perrings, and D. Pimental (1995), 'Economic growth, carrying capacity, and the environment', Science 268: 520-521.

Baltagi, B.H. (1995), Econometric Analysis of Panel Data, New York: John Wiley \& Sons.

Barbier, E.B. (1997), 'Introduction to the environmental Kuznets curve special issue', Environment and Development Economics 2: 369-381.

Barbier, E.B., J.C. Burgess, and A. Markandya (1991), 'The economics of tropical deforestation', AMBIO 20: 55-58.

Barro, R.J. (1996), 'Democracy and growth', Journal of Economic Growth 1: 1-27.

Bhattarai, M. and M.D. Hammig (2000), 'An empirical investigation of the environmental Kuznets curve for deforestation in Latin America’, Selected paper, Southern Agricultural Economics Association annual meetings, Lexington, Kentucky.

Bhattarai, M. and M.D. Hammig (2001), 'Institutions and the environmental Kuznets curve for deforestation: A cross-country analysis for Latin America, Africa, and Asia', World Development 29: 995-1010.

Bhattarai, M. (2000), 'The environmental Kuznets curve for deforestation in Latin America, Africa and Asia: Macroeconomics and institutional perspectives', Unpublished PhD dissertation, Clemson University, Clemson, SC.

Binswanger, H.P. (1991), 'Brazilian policies that encourage deforestation in the Amazon’, World Development 19: 821-829.

Brown, K. and D.W. Pearce, eds. (1994), The Causes of Tropical Deforestation: The Economic and Statistical Analysis of Factors Giving Rise to the Loss of Tropical Forests, Vancouver: UBC Press. 
Burgess, J.C. (1992), 'Economic analysis of the cause of tropical deforestation', Discussion Paper, DP 92-03, London Environmental Economics Centre, London.

Cropper, M., and C. Griffiths (1994), 'The interaction of population growth and environmental quality’, American Economic Review 84: 250-254.

Deacon, R.T. (1994), 'Deforestation and the rule of law in a cross section of countries', Land Economics 70: 414-430.

Ehrhardt-Martinez, K. (1998), 'Social determinants of deforestation in developing countries: A cross-national study’, Social Forces 77: 567-586.

Ekins, P. (1997), 'The Kuznets curve for the environment and economic growth: Examining the evidence', Environment and Planning 29: 805-830.

FAO (1997), State of the World's Forest, Rome: United Nations Food and Agricultural Organization.

Gastil, R.D. (1987), Freedom in the World, Westport, CT: Greenwood Press.

Gibson, C.C., E. Ostrom, and M.A. McKean (2000), 'Forests, people, and

governance: Some initial theoretical lessons', In Gibson, C.C., M.A. McKean and E.

Ostrom, eds., People and Forests: Communities, Institutions, and Governance,

Cambridge, MA: The MIT Press.

Godoy, R., S. Groff, and K. O’Neill (1998), 'The role of education in neotropical deforestation: Household evidence from Amerindians in Honduras', Human Ecology 26: 649-675.

Greene, W.H. (1997), Econometric Analysis, Englewood Cliffs, NJ: Prentice Hall.

Grossman, G.M. and A.B. Krueger (1991), 'Environmental Impact of a North American Free Trade Agreement', Working Paper No: 3914, National Bureau of Economic Research, Cambridge, MA.

Hsiao, C. (1986), Analysis of Panel Data, Econometric Society Monographs No. 11. Cambridge, UK: Cambridge University Press.

Isham, J., D. Kaufmann, and L. Pritchett (1997), 'Civil liberties, democracy, and the performance of government projects', The World Bank Economic Review 11: $219-42$. 
Kahn, J.R. and J.A. McDonald (1995), 'Third-world debt and tropical deforestation', Ecological Economics 12: 107-123.

Knack, S. and P. Keefer (1995), 'Institutions and economic performance: Cross-country tests using alternative institutional measures', Economics and Politics 7: 231-244.

Koop, G. and L. Tole (1999), 'Is there an environmental Kuznets curve for deforestation?’, Journal of Development Economics 58: 231-244.

Mather, A.S., C.L. Needle, and J. Fairbairn (1999), 'The environmental Kuznets curve and forest trends', Geography 84: 55-65.

Munasinghe, M. (1999), 'Is environmental degradation an inevitable consequence of economic growth: Tunneling through the environmental Kuznets curve,' Ecological Economics 29: 89-109.

Myers, N. (1994), ‘Tropical deforestation: Rates and patterns', in K. Brown and D.W. Pearce, eds., The Causes of Tropical Deforestation: The Economic and Statistical Analysis of Factors Giving Rise to the Loss of the Tropical Forests, Vancouver: UBC Press.

Myers, N. (1991), 'Tropical forest: Present status and future outlook', Climate Change 19: 3-32.

Norton, S.W. (1998), 'Property rights, the environment, and economic well-being', in P.J. Hill and R.E. Meiners, eds., Who Owns the Environment?, Lanham, MD: Rowman \& Littlefield.

Palo, M. (1994), 'Population and deforestation', in K. Brown and D.W. Pearce, eds., The Causes of Tropical Deforestation: The Economic and Statistical Analysis of Factors Giving Rise to the Loss of the Tropical Forests, Vancouver: UBC Press.

Panayotou, T. (1997), 'Demystifying the environmental Kuznets curve: Turning a black box into a policy tool’, Environment and Development Economics 2:465-484.

Panayotou, T. (1995), 'Environmental degradation at different stages of economic development', in I. Ahmed and J.A. Doeleman, eds., Beyond Rio: The Environmental Crisis and Sustainable Livelihoods in the Third World, ILO Studies Series, New York: St. Martin’s Press.

Repetto, R. and M. Gillis, eds., (1988), Public Policies and the Misuses of Forest Resources, New York: Cambridge University Press.

Samuelson, P. (1976), ‘Economics of forestry in an evolving society’, Economic Inquiry 14: 466-492. 
Scully, G.W. (1992), Constitutional Environments and Economic Growth, Princeton, NJ: Princeton University Press.

Seldon, T.M. and D. Song (1994), 'Environmental quality and development: Is there a Kuznets curve for air pollution emission?', Journal of Environmental Economics and Management 27: 147-162.

Shafik, N. and S. Bandhyopadhyay (1992), 'Economic growth and environmental quality: Time series and cross section evidence', Working Paper for the World Development Report 1992, Washington, DC: The World Bank.

Shafik, N. (1994), 'Macroeconomic causes of deforestation: Barking up the wrong tree?', in Brown, K. and D.W. Pearce, eds., The Cause of Tropical Deforestation: The Economic and Statistical Analysis of Factors Giving Rise to the Loss of the Tropical Forests, Vancouver: UBC Press.

Sokoloff, K.L. and S.L. Engerman (2000), 'Institutions, factor endowments, and path of development in the new world', Journal of Economic Perspectives 14: 217-232.

Southgate, D., and C.F. Runge (1990), 'The institutional origins of deforestation in Latin America’, Department of Agricultural and Applied Economics Staff Paper 90-5, University of Minnesota, Minneapolis.

Southgate, D. (1994), 'Tropical deforestation and agricultural development in Latin America', in Brown, K. and D.W. Pearce, eds., The Cause of Tropical Deforestation: The Economic and Statistical Analysis of Factors Giving Rise to the Loss of the Tropical Forests, Vancouver: UBC Press.

Southgate, D., R. Sierra, and L. Brown (1991), 'The causes of tropical deforestation in Ecuador: A statistical analysis’, World Development 19: 1145-1151.

Stern, D.I., M.S. Common, and E.B. Barbier (1996), 'Economic growth and environmental degradation: The environmental Kuznets curve and sustainable development', World Development 24: 1151-1160.

Summers, R. and A. Heston (1991), 'The Penn world table (Mark 5.5): An expanded set of international comparisons 1950-1988', Quarterly Journal of Economics 106: 327-68.

Templeton, S.R. and S.J. Scherr (1999), 'Effects of demographic and related microeconomic change on land quality in hills and mountains of developing countries', World Development 27: 903-918.

World Bank (1998), World Development Indicators CD Rom data Sets, Washington DC: The World Bank. 
World Resources Institute (1998-99), World Resources Datasets CD-Rom, Washington DC: World Resources Institute.

Walker, R. (1993), 'Deforestation and economic development', Canadian Journal of Regional Science 16: 481-497.

Yandle, B. and X.D. Qin (1998), 'Environmental Kuznets curve, property rights, and learning', Working Paper, Center for Policy and Legal Studies, Clemson University, Clemson, SC. 